\title{
Immunomodulatory effects of prolactin and growth hormone in the tilapia, Oreochromis mossambicus
}

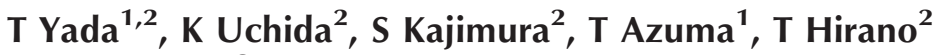 \\ and E G Grau ${ }^{2}$ \\ ${ }^{1}$ Nikko Branch, National Research Institute of Aquaculture, 2482-3 Chugushi, Nikko, Tochigi 321-1661, Japan \\ ${ }^{2}$ Hawaii Institute of Marine Biology, University of Hawaii, Kaneohe, Hawaii 96744, USA \\ (Requests for offprints should be addressed to T Yada; Email: yadat@fra.affrc.go.jp)
}

\begin{abstract}
To clarify the roles of prolactin (PRL) and GH in the control of the immune system, the effects of environmental salinity, hypophysectomy, and PRL and GH administration on several immune functions were examined in tilapia (Oreochromis mossambicus). Transfer from fresh water (FW) to seawater (SW) did not alter plasma levels of immunoglobulin $\mathrm{M}$ (IgM) and lysozyme. The superoxide anion $\left(\mathrm{O}_{2}^{-}\right)$production in head kidney leucocytes accompanied by phagocytosis was elevated in SWacclimated fish over the levels observed in FW fish. Hypophysectomy of the fish in FW resulted in a reduction in $\mathrm{O}_{2}^{-}$production in leucocytes isolated from the head kidney, whereas there was no significant change in plasma levels of IgM or lysozyme. Treatment with tilapia GH and PRLs ( $\mathrm{PRL}_{177}$ and $\mathrm{PRL}_{188}$ ) enhanced $\mathrm{O}_{2}^{-}$production in
\end{abstract}

vitro in head kidney leucocytes in a dose-related manner. Extrapituitary expression of two PRLs, GH and IGF-I mRNA was detected in lymphoid tissues and cells such as head kidney, spleen, intestine and leucocytes from peripheral blood and head kidney. PRL-receptor mRNA was detected in head kidney leucocytes, and the level of expression was higher in SW-acclimated fish than that in FW fish. Treatment with $\mathrm{PRL}_{177}$ caused higher production of $\mathrm{O}_{2}^{-}$in the head kidney leucocytes isolated from SW tilapia than that from FW fish. In view of the fact that PRL acts antagonistically to osmoregulation in SW, its immunomodulatory actions in this euryhaline fish would appear to be independent of its osmoregulatory action.

Journal of Endocrinology (2002) 173, 483-492

\section{Introduction}

Prolactin (PRL) and growth hormone (GH) are known to enhance immune functions in fish as in mammals (for reviews see Balm 1997, Clark 1997, Harris \& Bird 2000). The phagocytic activity of fish leucocytes is stimulated by administration of PRL or GH (Balm 1997, Harris \& Bird 2000). PRL and GH have also been found to enhance the mitotic activity of leucocytes of the chum salmon (Oncorhynchus keta), and are necessary to maintain circulating levels of immunoglobulin $\mathrm{M}(\mathrm{IgM})$ in the rainbow trout (Oncorhynchus mykiss) (Sakai et al. 1996a, Yada et al. 1999). In many teleost species, PRL maintains hydro-mineral balance in fresh water (FW), whereas $\mathrm{GH}$ has been found to facilitate acclimation to seawater (SW) in several euryhaline species including salmonids and Mozambique tilapia (Oreochromis mossambicus) (McCormick 1995, Sakamoto et al. 1997). In salmonids, the immunomodulatory effect of $\mathrm{GH}$ seems to be related to its role in osmoregulation. After transfer of the brown trout (Salmo trutta) from FW to SW, the increase in plasma $\mathrm{GH}$ was well correlated with the increases in plasma lysozyme and phagocytosis of leucocytes (Marc et al. 1995). Administration of homologous GH stimulated plasma lysozyme and phagocytosis of leucocytes in the rainbow trout, along with enhancement of osmoregulatory ability in SW (Yada et al. 2001). Plasma levels of GH are sensitive to the changes in environmental salinity in the tilapia (Yada et al. 1994, Shepherd et al. 1997a). However, the effect of environmental salinity and administered PRL or $\mathrm{GH}$ on immune functions has not been investigated in tilapia.

The tilapia pituitary produces two distinct PRLs, $\mathrm{PRL}_{177}$ and $\mathrm{PRL}_{188}$ (Specker et al. 1985, Yamaguchi et al. 1988). $\mathrm{PRL}_{177}$ shows a potent somatotropic action (Shepherd et al. 1997b). On the other hand, only one class of PRL-receptor (PRL-R) was identified by Scatchard analysis with radiolabeled tilapia PRLs in the osmoregulatory tissues of Nile tilapia (Oreochromis niloticus), and its binding with $\mathrm{PRL}_{188}$ was higher than with $\mathrm{PRL}_{177}$ (Auperin et al. 1994, 1995). Similarly, a single cDNA sequence has been cloned from two species of the tilapia (Oreochromis mossambicus and Oreochromis niloticus) (Sandra et al. 1995, Shiraishi et al. 1999). Expression of the PRL-R 
mRNA in the spleen, head kidney and peripheral blood leucocytes has been detected by Northern blot analysis in the Nile tilapia, suggesting hemopoietic or immunomodulatory action of PRL (Sandra et al. 2000).

The present study was carried out to clarify whether PRLs and GH have immunoregulatory roles in the tilapia. Endogenous levels of these hormones were modified by SW acclimation and hypophysectomy, and changes in plasma levels of IgM and lysozyme as well as superoxide anion $\left(\mathrm{O}_{2}^{-}\right)$production in phagocytic leucocytes were examined. Effects of PRLs and $\mathrm{GH}$ on $\mathrm{O}_{2}^{-}$production were examined in cultured leucocytes. Extrapituitary expression of PRL, GH and insulin-like growth factor-I (IGF-I) in lymphoid tissues and cells was examined by RT-PCR and RNase protection assay.

\section{Materials and Methods}

\section{Fish}

Mozambique tilapia (Oreochromis mossambicus), weighing 50-100 g, were reared at the Hawaii Institute of Marine Biology for successive generations in outdoor tanks, supplied with a continuous flow of $\mathrm{FW}$ at $24 \pm 2{ }^{\circ} \mathrm{C}$ under natural photoperiod. They were fed twice daily with commercial dry diet (ProForm; Agro Pacific, Chilliwaeck, British Columbia, Canada), approximately $5 \%$ of body weight per day. Some fish were transferred from FW to $60 \% \mathrm{SW}$. After 1 week in $60 \% \mathrm{SW}$, they were transferred to full-strength SW (35 p.p.t.) and acclimated for more than 1 month.

\section{Hypophysectomy}

After anesthetization in tricaine methane sulfonate (MS222; Sigma, St Louis, MO, USA; 0.15 g/l) buffered with $\mathrm{NaHCO}_{3}(0 \cdot 2 \mathrm{~g} / \mathrm{l})$, fish in FW were hypophysectomized or sham-operated through the orbit (Nishioka 1980). After the operation, hypophysectomized fish were reared in outdoor $25 \% \mathrm{SW}$ tanks for 1 week for recovery. Sham-operated and intact fish were also transferred to $25 \%$ SW. They were fed as described above. Survival during the subsequent week was about 95\% for both hypophysectomized and sham-operated fish.

\section{Isolation of leucocytes}

Fish were anesthetized with MS222, and blood was collected from the caudal vessels using a syringe treated with heparin ammonium (Sigma; $200 \mathrm{U} / \mathrm{ml}$ ). Leucocytes from the peripheral blood and head kidney were isolated as described by Espelid et al. (1996) and Sakai et al. (1996b) with slight modifications. Blood $(500 \mu \mathrm{l})$ was mixed with $1 \mathrm{ml}$ minimum essential medium (MEM; Sigma) with Eagle's salt, buffered with 7.5\% $\mathrm{NaHCO}_{3}(\mathrm{pH} \quad 7 \cdot 6)$ containing $0 \cdot 2 \%$ heparin sodium (Sigma). The mixture was placed on a 54\% Percoll (Pharmacia, Uppsala, Sweden) cushion and centrifuged at $400 \boldsymbol{g}$ for $25 \mathrm{~min}$. The head kidney was placed in MEM, dissociated with forceps, and filtered with nylon mesh $(37 \mu \mathrm{m})$. The dissociated cells were placed on 34/51\% Percoll cushions and centrifuged. The leucocyte band was harvested, washed with phosphate-buffered saline $(\mathrm{pH} 7 \cdot 6)$, and suspended in MEM containing 5\% tilapia serum obtained from FWacclimated tilapia. Viable leucocytes were counted by trypan blue exclusion (viability $>90 \%$ ). The leucocytes were used for the analysis of $\mathrm{O}_{2}^{-}$production as described below. Aliquots of leucocytes and tissues were frozen in liquid nitrogen immediately after isolation and stored at $-80{ }^{\circ} \mathrm{C}$ until RNA extraction.

\section{IgM, lysozyme and $\mathrm{O}_{2}^{-}$production}

Plasma IgM levels were estimated by a specific enzymelinked immunosorbent assay as described by Takemura (1993). Lysozyme activity in the plasma was measured according to the turbidimetric method using hen's egg white lysozyme (Sigma) as a standard (Takemura \& Takano 1995). Plasma cortisol levels were measured by radioimmunoassay as described by Eckert et al. (2001).

The $\mathrm{O}_{2}^{-}$production in blood and head kidney leucocytes was determined as the reduction of nitroblue tetrazolium (NBT; Sigma) (Sakai et al. 1996b). In brief, isolated leucocytes were adjusted to $10^{7}$ cells $/ \mathrm{ml}$, and $50 \mu \mathrm{l}$ was seeded into 96-well microplates. They were mixed with $50 \mu \mathrm{l}$ MEM containing NBT $(1 \mathrm{mg} / \mathrm{ml})$ with or without zymosan A (Sigma), lipopolysaccharide (LPS; Sigma) or phorbol myristate acetate (PMA; Sigma) as the stimulants for $\mathrm{O}_{2}^{-}$production. After incubation for $1 \mathrm{~h}$ at $25^{\circ} \mathrm{C}$, culture media were aspirated and the cells were fixed with methanol for several minutes. They were air-dried, and dissolved in $120 \mu \mathrm{l} 2 \mathrm{M} \mathrm{KOH}$ and $140 \mu \mathrm{l}$ of dimethyl sulfoxide (Sigma). Optical density was measured with a microplate reader (SpectraCount; Packard, Meriden, CT, USA) at $620 \mathrm{~nm}$.

In vitro effects of $\mathrm{PRL}$ and $\mathrm{GH}$ on $\mathrm{O}_{2}^{-}$production were also examined using the head kidney leucocytes. Tilapia $\mathrm{PRL}_{177}, \mathrm{PRL}_{188}$ and GH were prepared as described by Yamaguchi et al. (1988, 1991); purity was confirmed by HPLC. They were dissolved in a minimum volume of $0 \cdot 1 \mathrm{M} \mathrm{NaOH}$ and diluted with the culture media. Head kidney leucocytes were incubated in the culture media containing hormones for $4 \mathrm{~h}$ at $25^{\circ} \mathrm{C}$, before analysis of $\mathrm{O}_{2}^{-}$production.

\section{$R N A$ extraction and $R T-P C R$}

Total RNA from each leucocyte fraction or tissue was extracted using TRI REAGENT (Molecular Research Center, Cincinnati, OH, USA), and quantified at $260 \mathrm{~nm}$ with a DU 650 spectrophotometer (Beckman, Fullerton, 
CA, USA). The PCR primers were designed to amplify $\mathrm{PRL}_{177}$ (5'-CTATAGACAGGGTTCTCGCG-3', forward; 5'-GCAGGACAGCAGTTTGGTAA-3', reverse), PRL $_{188}$ (5'-GTCAGATTTGATGTCCCTGG-3', forward; 5'-GCAGGACAGCAGAAAGTTGA-3', reverse), GH (5'-CAGCTGTCGGTTGTGTGTTT-3', forward; 5'-CAGCAGCAAGATTCCCGTTT-3', reverse), IGF-I (5'-ATAAACCAACAGGCTATGGC-3', forward; 5'TTCTGGTGGACTTCCTTGA-3', reverse), PRL-R (5'-CAGAGATCAAATGCCGTTCTCC-3', forward; 5'-ATTTCAGGCAGCCGTCATGATC-3', reverse), and $\beta$-actin (5'-CATGAAGTGCGACGTTGACA- ${ }^{\prime}$, forward; 5'-CACATCTGCTGGAAGGTGGA-3', reverse) based on Swennen et al. (1992), Reinecke et al. (1997), Chen et al. (1998), Sekkali et al. (1999), Shiraishi et al. (1999), Takeuchi (2000) and N R Staten (personal communication). After DNase treatment, RT-PCR was performed with an Access RT-PCR System (Promega Corporation, Madison, WI, USA), BcaBEST RNA PCR Kit version 1.1 (Takara, Tokyo, Japan) and AmpliTaqGold DNA Polymerase (Roche Molecular Systems, Branchburg, NJ, USA) using a PTC-200 Peltier Thermal Cycler (MJ Research Inc., Waltham, MA, USA) and a GeneAmp 2400 PCR System (Perkin Elmer, Norwalk, CT, USA). The PCR conditions for $\mathrm{PRL}_{177}$, $\mathrm{PRL}_{188}, \mathrm{GH}$ and $\beta$-actin were: $94{ }^{\circ} \mathrm{C}$ for $30 \mathrm{~s}, 56{ }^{\circ} \mathrm{C}$ for $30 \mathrm{~s}, 72{ }^{\circ} \mathrm{C}$ for $1 \mathrm{~min}$, for 30 cycles. Those for IGF-I and PRL-R were 53 and $59{ }^{\circ} \mathrm{C}$ respectively instead of $56{ }^{\circ} \mathrm{C}$ for annealing. Total RNA from the pituitary of channel catfish (Ictalurus punctatus) was used as the negative control. After amplification, the products were analyzed by a $1 \%$ agarose gel and stained with ethidium bromide.

\section{RNase protection assay}

The antisense riboprobe for PRL-R was generated using a cDNA fragment of PRL-R subunit clone (Shiraishi et al. 1999). The cDNA fragment was subcloned into pBluescript II (Stratagene, San Diego, CA, USA). The identity and orientation of the inserted cDNA was confirmed by automated nucleic acid sequencing on a CEQ 2000XL DNA sequencer (Beckman). Riboprobe was prepared using the MAXIscript in vitro transcription kit (Ambion, Austin, TX, USA) with $\left[\alpha_{-}{ }^{32} \mathrm{P}\right] \mathrm{UTP}$ (NEN, Boston, MA, USA). The RNA polymerase used was T3 or T7, depending on the orientation of the insert. Free nucleotide was removed from the labeled riboprobe by MicroSpin S-200HR (Amersham Pharmacia Biotech., Piscataway, NJ, USA). The reference (sense) RNA was transcribed from the subclone using MAXIscript. For construction of the standard curve, serial dilutions of reference (sense) RNA were made to construct standard curves of $0 \cdot 04-$ $40 \mathrm{amol}$, converting the range of mRNA levels expected in the unknown samples.

The RNase protection assay was carried out using an RPA III ribonuclease protection assay kit (Ambion). Total
RNA from head kidney leucocytes was extracted as described above. DNA was also extracted from each sample and quantified for standardization of the assay. Sample RNA was mixed with riboprobe, diluted in hybridization buffer, and incubated overnight at $56^{\circ} \mathrm{C}$. After hybridization, unprotected single-stranded RNA was digested with a diluted RNase digestion buffer (RNase A/RNase T1 mix; Ambion) for $30 \mathrm{~min}$ at $37^{\circ} \mathrm{C}$. RNA duplexes were then precipitated and resuspended in gel loading buffer. They were fractionated through a $5 \%$ acrylamide $/ 8 \mathrm{M}$ urea gel. The gel was mounted on a $3 \mathrm{MM}$ paper (Whatman, Cliton, NJ, USA), processed for autoradiography using X-OMT AR film (Kodak, Rochester, NY, USA), and then quantified using a computer program, Scion Image (Frederick, MD, USA).

\section{Statistical analysis}

Significance of the difference between two groups was analyzed by ANOVA followed by Duncan's multiple range test or by Mann-Whitney $U$ test. Calculations were performed using a computer program, STATISTICA (StatSoft, Tulsa, OK, USA).

\section{Results}

As shown in Fig. 1, $\mathrm{O}_{2}^{-}$production in leucocytes isolated from the head kidney was significantly $(P<0 \cdot 05)$ higher in SW-acclimated fish than that in FW fish, whereas there was no change in the leucocytes isolated from peripheral blood. Plasma levels of IgM and lysozyme were not affected by environmental salinity.

When fish in FW were hypophysectomized, the plasma level of cortisol decreased markedly 1 week after the operation (Fig. 2). Sham-operated fish showed a tendency toward an increase in plasma cortisol compared with the intact fish, although the difference was not significant. Plasma levels of IgM and lysozymes were not affected by hypophysectomy. Superoxide anion production in phagocytic leucocytes isolated from the head kidney decreased significantly $(P<0 \cdot 05)$ in the hypophysectomized fish from levels observed in intact and sham-operated fish.

Figure 3 shows in vitro effects of tilapia PRLs and GH $(5 \mathrm{nM}$ or $100 \mathrm{ng} / \mathrm{ml})$ on $\mathrm{O}_{2}^{-}$production in head kidney leucocytes stimulated by zymosan, LPS or PMA. Even without stimulant, incubation with $\mathrm{PRL}_{188}$ or $\mathrm{GH}$ for $4 \mathrm{~h}$ significantly $(P<0 \cdot 05)$ enhanced the basal production of $\mathrm{O}_{2}^{-}$in head kidney leucocytes. Of the three stimulants used, the effects of PMA were strongest, followed by zymosan and LPS. Treatment with $\mathrm{PRL}_{177}$ resulted in a significant $(P<0 \cdot 05)$ increase in $\mathrm{O}_{2}^{-}$production stimulated by zymosan, LPS and PMA. $\mathrm{PRL}_{188}$ and GH produced a significant $(P<0 \cdot 05)$ elevation in $\mathrm{O}_{2}^{-}$ production when stimulated by LPS. 

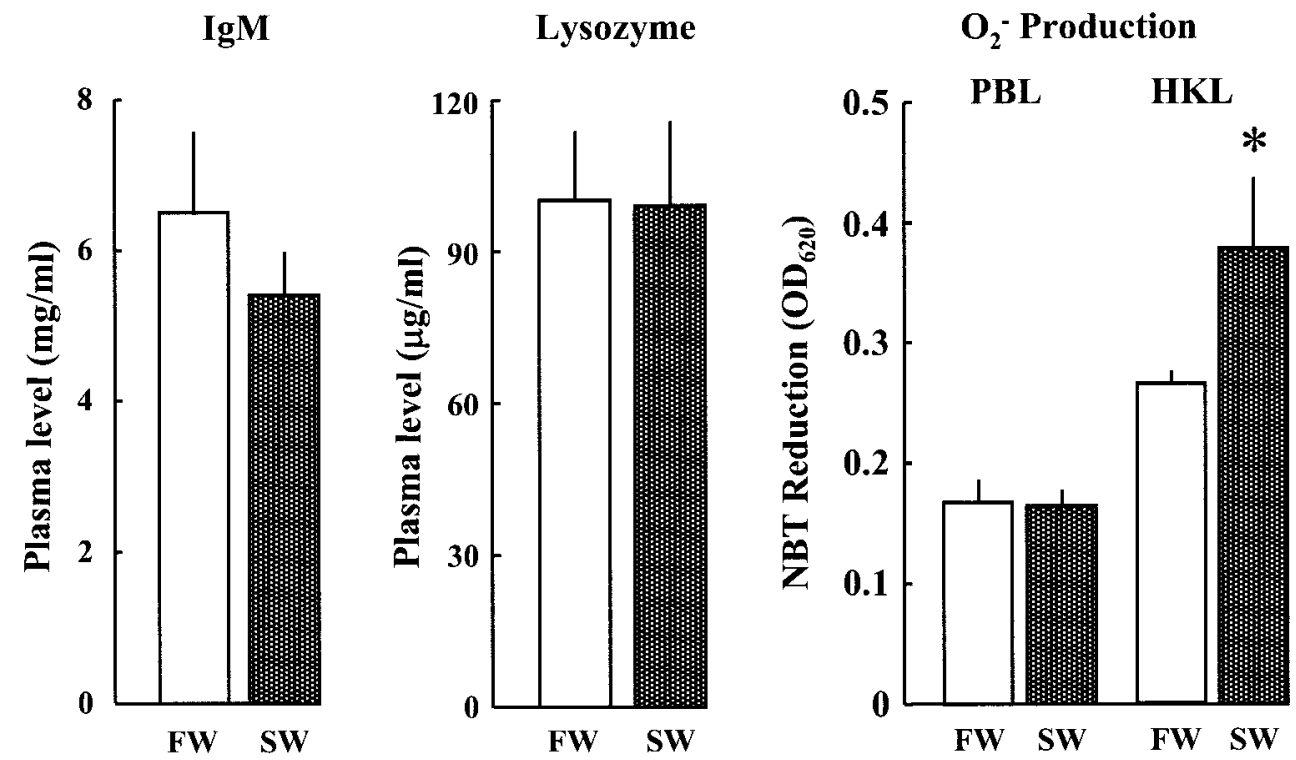

Figure 1 Effects of acclimation to SW (35 p.p.t., shaded bars) on plasma IgM and lysozyme activity, and zymosan $(100 \mu \mathrm{g} / \mathrm{ml})$-stimulated $\mathrm{O}_{2}^{-}$production in the peripheral blood leucocytes (PBL) and head kidney leucocytes $(\mathrm{HKL})$. Data are expressed as means \pm S.E.M. $(n=5)$. ${ }^{\star} P<0 \cdot 05$ compared with the fish kept in FW (open bars).

\section{Cortisol}

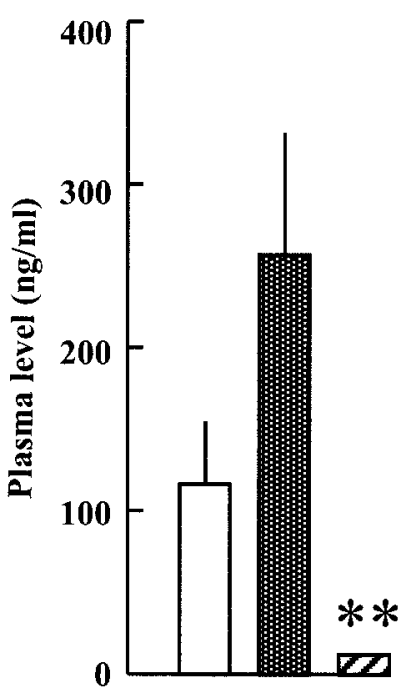

$\operatorname{IgM}$

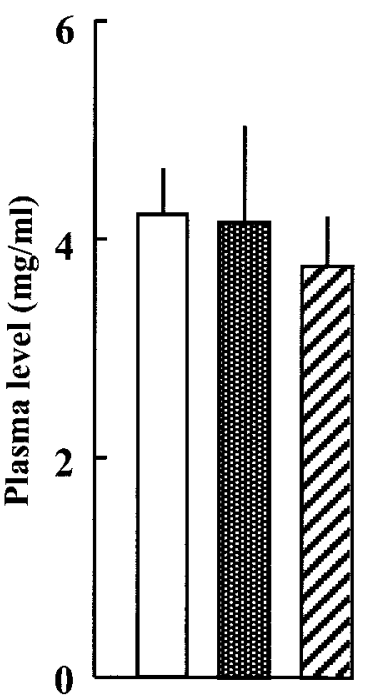

Lysozyme

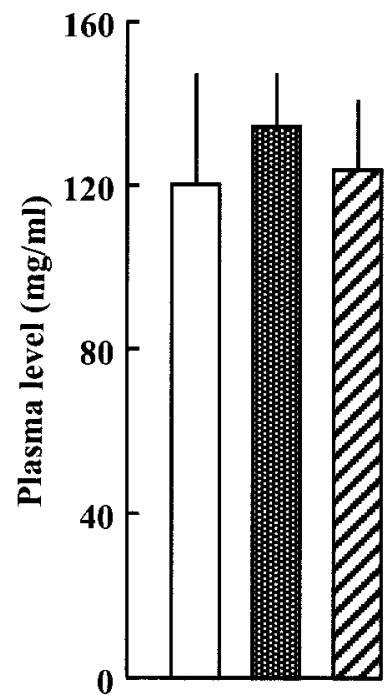

$\mathrm{O}_{2}^{-}$- Production

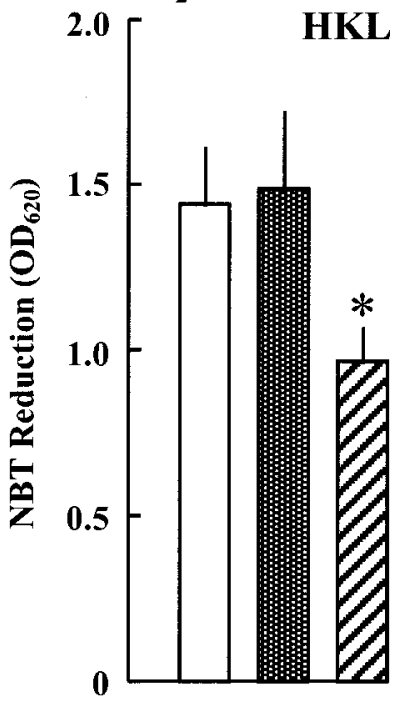

\section{$\square$ Intact 藍 Sham $\square$ Hypox}

Figure 2 Effects of hypophysectomy on plasma cortisol, IgM and lysozyme activity, and zymosan (100 $\mu \mathrm{g} / \mathrm{ml}_{)}$-stimulated $\mathrm{O}_{2}^{-}$production in the head kidney leucocytes (HKL). Data are expressed as means \pm S.E.M. $(n=5-9)$. ${ }^{*} P<0 \cdot 05,{ }^{* *} P<0 \cdot 01$ compared with the shamoperated fish.

In the next experiment, the dose-dependency of the effects of tilapia PRLs and $\mathrm{GH}$ was examined on $\mathrm{O}_{2}^{-}$ production stimulated by LPS (Fig. 4). $\mathrm{PRL}_{177}$, PRL 188 and $\mathrm{GH}$ stimulated the $\mathrm{O}_{2}^{-}$production significantly $(P<0 \cdot 05$ or $P<0 \cdot 01)$ at all doses examined, except for $5 \mathrm{pM} \mathrm{PRL} \mathrm{PR}_{188}$. Furthermore, stimulation of $\mathrm{O}_{2}^{-}$production was found to be dose-related for all the hormones.

Figure 5 shows the extrapituitary expression of PRL and GH genes in lymphoid tissues and cells. Both PRLs were expressed ubiquitously in lymphoid tissues and cells, such 


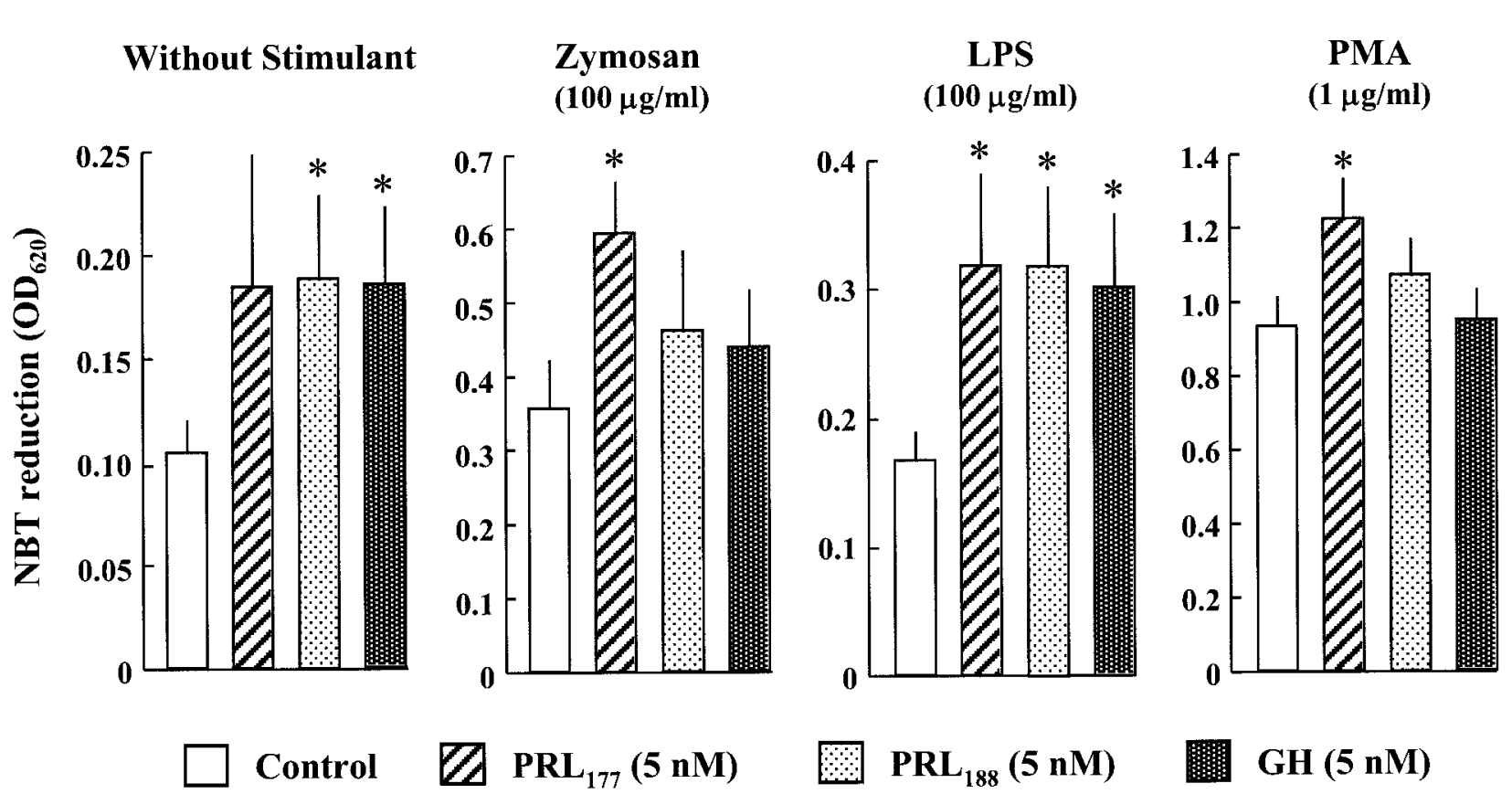

Figure 3 In vitro effects of tilapia PRLs and GH on zymosan-, LPS- or PMA-stimulated $\mathrm{O}_{2}^{-}$production in leucocytes isolated from the head kidney. Cells were incubated with $\mathrm{PRL}_{177}, \mathrm{PRL}_{188}$ or $\mathrm{GH}(5 \mathrm{nM}$ or $100 \mathrm{ng} / \mathrm{ml})$ for $4 \mathrm{~h}$, and $\mathrm{O}_{2}^{-}$production was estimated. Data are expressed as means \pm S.E.M. $(n=6)$. ${ }^{*} P<0 \cdot 05$ compared with the controls without hormone.

as head kidney, spleen, intestine and leucocytes from peripheral blood and head kidney. GH expression was limited, but strong expression was detected in the leucocytes isolated from the peripheral blood. A lower level of GH mRNA was detected in the intestine. IGF-I mRNA was detected in all the lymphoid tissues examined, but not in leucocytes from the blood and head kidney.

The results of RT-PCR and the RNase protection assay clearly indicated expression of PRL-R mRNA in leucocytes isolated from the head kidney (Fig. 6). Figure 7A shows the results of the quantitative RNase protection assay for PRL-R mRNA expressed in head kidney leucocytes. PRL-R mRNA level in head kidney leucocytes was three times higher in SW tilapia than in FW fish (Fig. 7B). Standardization with total RNA or number of the cells showed essentially the same results as that with total DNA (data not shown).

Figure 8 shows the effect of environmental salinity on LPS-stimulated $\mathrm{O}^{-}$production in head kidney leucocytes pretreated with $\mathrm{PRL}_{177}$. Superoxide anion production in leucocytes from SW-acclimated fish was significantly $(P<0 \cdot 01)$ higher than that in those from FW fish, regardless of pretreatment with $\mathrm{PRL}_{177}$. In leucocytes from FW fish, $\mathrm{O}_{2}^{-}$production was enhanced with $\mathrm{PRL}_{177}$ $(P<0 \cdot 05)$. However, $\mathrm{PRL}_{177}$ did not produce further enhancement of $\mathrm{O}_{2}^{-}$production in leucocytes from SW fish, as compared with the untreated cells from SW fish.

\section{Discussion}

The present study clearly showed that the PRL-R gene is expressed in phagocytic leucocytes isolated from the head kidney of tilapia. This is in accord with the in vitro stimulation by $\mathrm{PRL}_{177}$ and $\mathrm{PRL}_{188}$ of $\mathrm{O}_{2}^{-}$production in head kidney leucocytes accompanied by phagocytosis. Activation of phagocytosis and subsequent $\mathrm{O}_{2}^{-}$production as a killing mechanism of pathogens has been observed after PRL administration in fish (Balm 1997, Harris \& Bird 2000). Expression of PRL-R was also detected in the peripheral blood leucocytes of Nile tilapia (Sandra et al. 2000). Although we did not examine the effect of tilapia PRLs and $\mathrm{GH}$ on $\mathrm{O}_{2}^{-}$production in the peripheral blood leucocytes, the presence of PRL-R mRNA implies involvement of PRL in the regulation of the function of blood leucocytes too. PRL had also been found to enhance the other parameters of fish immunity including mitosis of leucocytes (Balm 1997, Harris \& Bird 2000). The fact that phagocytic leucocytes were activated after incubation for $4 \mathrm{~h}$ with tilapia PRLs indicates that PRL enhances cellular immunity of fish independently of its hemopoietic action.

As in the present study, stimulatory effects of $\mathrm{GH}$ on fish immunity have been observed in several fish species. In vivo or in vitro administration of $\mathrm{GH}$ enhanced phagocytosis, mitosis and cytotoxic activity of leucocytes, and plasma hemolytic and lysozymic activities (Balm 1997, 


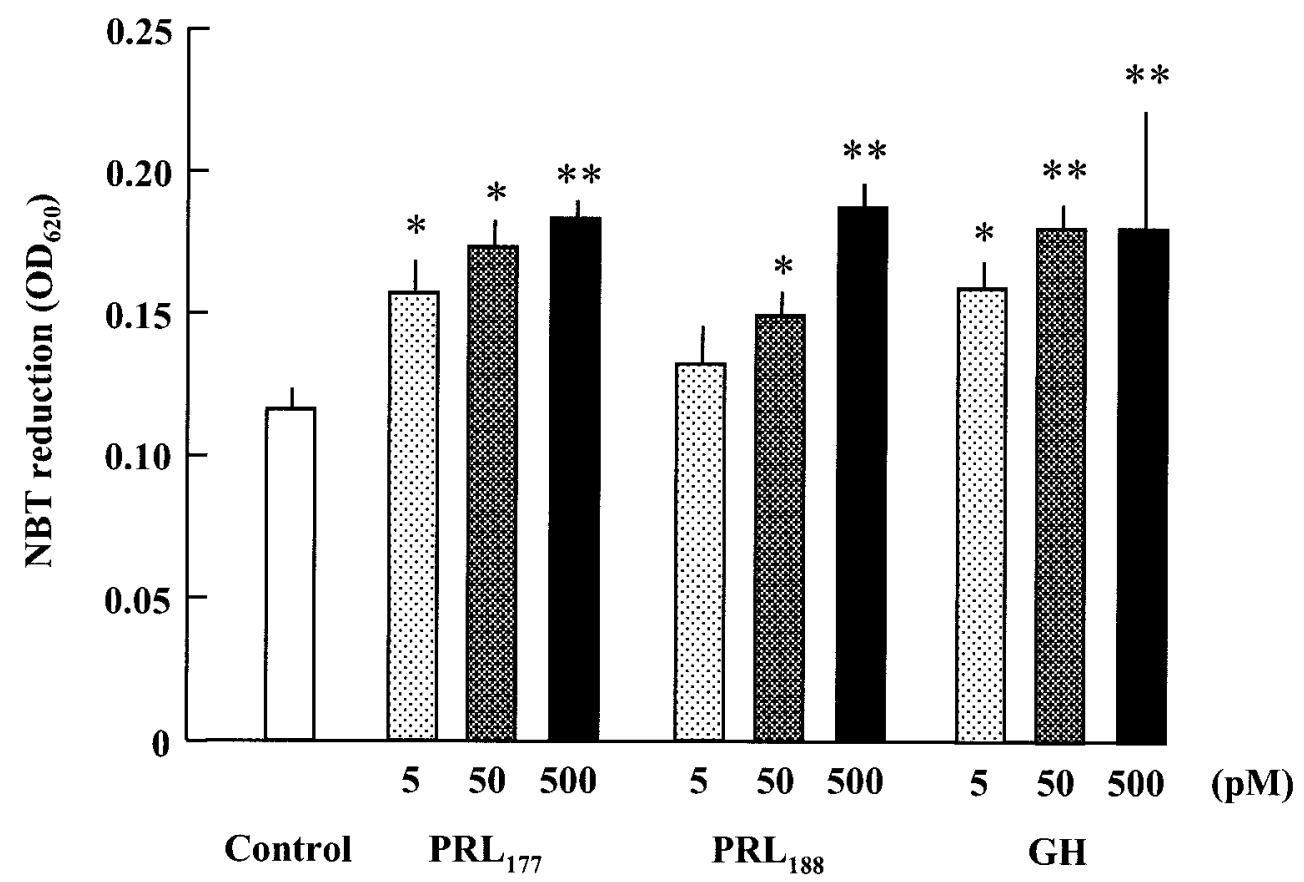

Figure 4 Dose-dependent effects of tilapia PRLs and GH on LPS $(100 \mu \mathrm{g} / \mathrm{ml})$-stimulated $\mathrm{O}_{2}^{-}$production in leucocytes isolated from the head kidney. Cells were incubated with $\mathrm{PRL}_{177}, \mathrm{PRL}_{188}$ or $\mathrm{GH}$ at concentrations of 5-500 $\mathrm{pM}(0 \cdot 1-10 \mathrm{ng} / \mathrm{ml})$ for $4 \mathrm{~h}$, and $\mathrm{O}_{2}^{-}$production was estimated. Data are expressed as means \pm S.E.M. $(n=8)$. ${ }^{*} P<0 \cdot 05,{ }^{* *} P<0 \cdot 01$ compared with the controls without hormone.

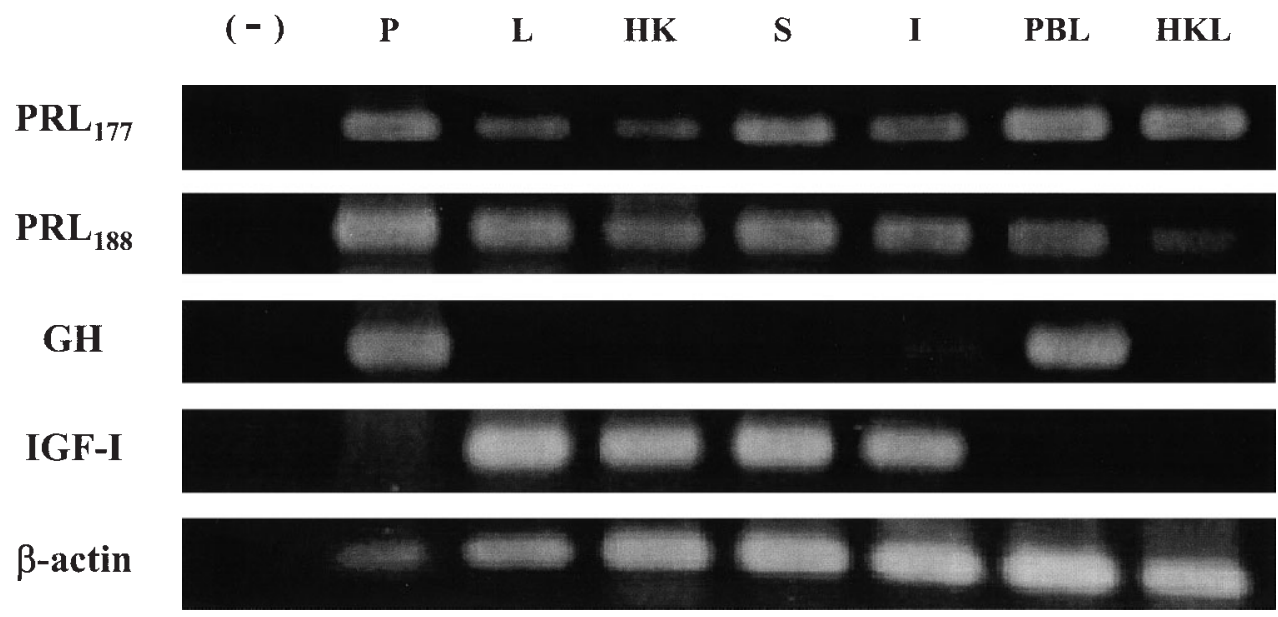

Figure 5 Expression of $\mathrm{PRL}_{177}, \mathrm{PRL}_{188}, \mathrm{GH}, \mathrm{IGF}-\mathrm{I}$ and $\beta$-actin mRNAs detected by RT-PCR in tissues and cells of the tilapia. ( - ), negative control with total RNA from the catfish pituitary; P, pituitary of the tilapia; $\mathrm{L}$, liver; HK, head kidney; S, spleen; I, intestine; PBL, peripheral blood leucocytes; HKL, head kidney leucocytes.

Harris \& Bird 2000, Yada et al. 2001). In rainbow trout, the decreased level of plasma IgM following hypophysectomy was restored by GH treatment (Yada et al. 1999). On the other hand, $\mathrm{PRL}_{177}$ shares considerable structural and functional overlaps with $\mathrm{GH}$, and hepatic GH radioreceptor assay revealed that $\mathrm{PRL}_{177}$ binds significantly to the tilapia GH receptor (Shepherd et al. 1997b). The similarity of the immunomodulatory effects of GH and PRL may be related the ability of $\mathrm{GH}$ receptor to bind $\mathrm{PRL}_{177}$. However, a radioreceptor assay of PRL in Nile tilapia revealed that tilapia PRL-R does not recognize GH (Auperin et al. 1995, Sandra et al. 1995). Thus, the presence of PRL-R in lymphoid cells would seem to indicate a direct action of PRL on immune functions. 
RT-PCR

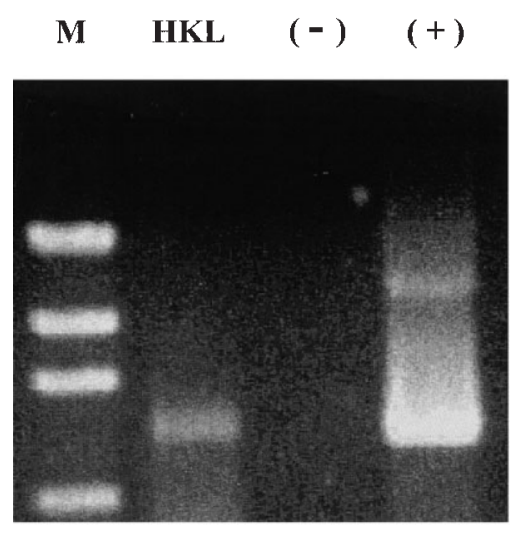

RPA

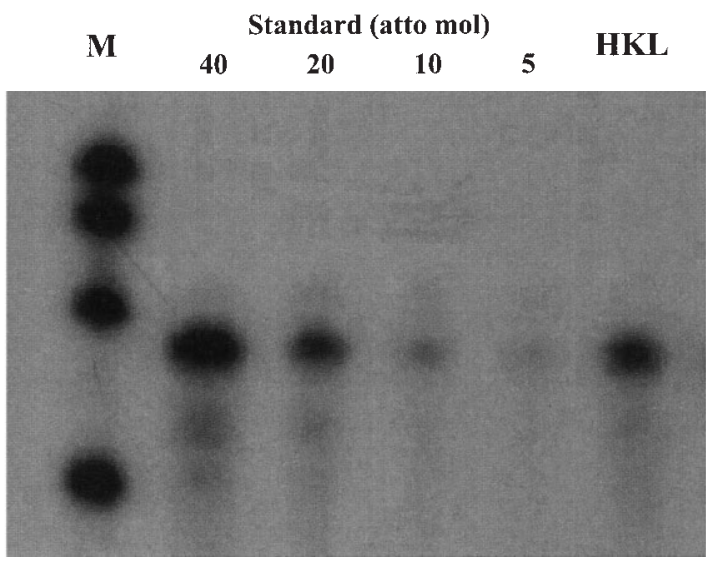

Figure 6 Detection of PRL-R mRNA in leucocytes from the head kidney by RT-PCR or RNase protection assay (RPA). M, size marker; HKL, head kidney leucocytes; $(-)$, negative control without reverse transcription; $(+)$, positive control with PRL-R cDNA sequence-containing plasmid.

A

FW

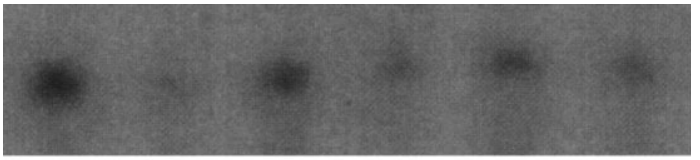

SW

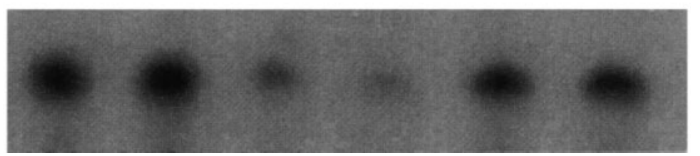

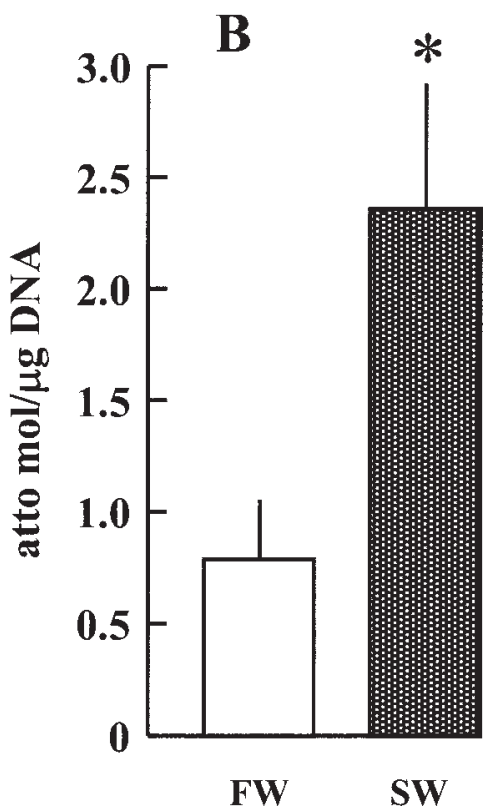

Figure 7 Effect of acclimation to SW (35 p.p.t., shaded bar) on PRL-R mRNA levels in the head kidney leucocytes. (A) RNase protection assay for PRL-R mRNA in head kidney leucocytes from FW- or SW-acclimated fish. Each lane represents a sample from an individual fish. (B) Quantification of mRNA level of PRL-R in the head kidney leucocytes. Data are expressed as means \pm S.E.M. $(n=6)$. ${ }^{\star} P<0 \cdot 05$ compared with the fish kept in FW (open bar).

Cortisol is well known to suppress fish immune functions in relation to various stresses (Balm 1997, Harris \& Bird 2000). In this study, however, sham-operation followed by a tendency to an increase in plasma cortisol levels did not show significant influence on immune functions. Although hypophysectomy resulted in a significant decrease in plasma cortisol, there was no enhancement of immune function, but a decrease in $\mathrm{O}_{2}^{-}$ production was observed in leucocytes. Changes in cortisol secretion caused by the operation did not show a suppressive effect on immunity in this study.

Enhancement of immune functions in high environmental salinity has been observed in salmonids (Marc et al. 1995, Yada et al. 2001). An increase in the secretion rate of $\mathrm{GH}$ estimated from the clearance of administered $\mathrm{GH}$ was observed during the course of SW acclimation of rainbow trout (Sakamoto et al. 1990). Increased secretion of GH in SW seems to facilitate not only osmoregulation 


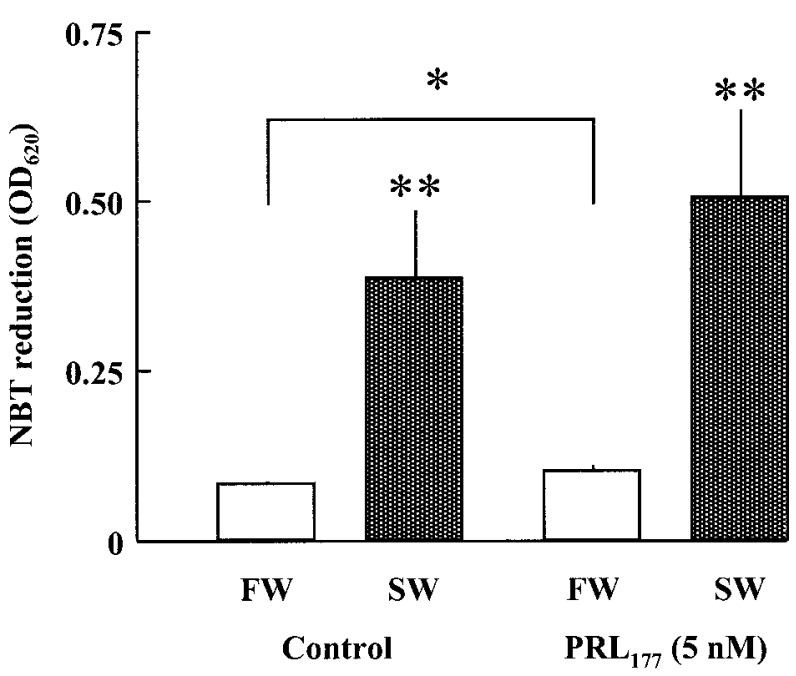

Figure 8 Effects of acclimation to SW (shaded bars) on LPS $(100 \mu \mathrm{g} / \mathrm{ml})$-stimulated $\mathrm{O}_{2}^{-}$production in the head kidney leucocytes pretreated with $\mathrm{PRL}_{177}$. Data are expressed as means \pm S.E.M. $(n=6) .{ }^{*} P<0 \cdot 05,{ }^{*} P<0 \cdot 01$ compared with the fish in FW (open bars).

but also immune functions. During acclimation of brown trout from FW to SW, plasma levels of GH exhibited positive correlation with plasma lysozyme levels as well as phagocytic activity of leucocytes (Marc et al. 1995). In rainbow trout, plasma lysozyme and phagocytic activity of leucocytes was stimulated by exogenous GH in parallel with the enhancement of hypo-osmoregulation in SW (Yada et al. 2001). Tilapia is another euryhaline species in which environmental salinity stimulates GH secretion (Yada et al. 1994, Shepherd et al. 1997a), with GH having a hypo-osmoregulatory or SW-adapting effect (Sakamoto et al. 1997). Stimulation of $\mathrm{O}_{2}^{-}$production in leucocytes isolated from the head kidney of the SW-acclimated tilapia is in accord with the increased secretion of GH in SW and the stimulatory effect of $\mathrm{GH}$ on $\mathrm{O}_{2}^{-}$production in vitro. As in salmonids, environmental salinity may modulate the immune system of tilapia through an increased secretion of endogenous $\mathrm{GH}$.

Transfer of the euryhaline species of teleosts, including tilapia, to SW always results in a decline in PRL secretion (Yada et al. 1994, McCormick 1995). The low plasma level of PRL in SW seems to favor acclimation to a hyperosmotic environment, since PRL exerts a sodiumretaining effect, which is inhibitory for hypoosmoregulation in SW (Sakamoto et al. 1997). Expression of PRL-R mRNA in the gill, one of the most important osmoregulatory organs in fish, was lower in SWacclimated tilapia than that in FW fish (Shiraishi et al. 1999, Prunet et al. 2000). In contrast, a radioreceptor assay revealed that the affinity and capacity of PRL-R in the tilapia gill, kidney and intestine were increased rapidly after transfer of Nile tilapia to SW and remained high for several weeks (Auperin et al. 1995, Sandra et al. 2001). In this study, leucocytes from the head kidney of SWacclimated tilapia showed a significant increase in the level of PRL-R mRNA. Although the kinetics of PRL-R expression in the tilapia leucocytes has not been examined, SW acclimation tended to enhance the response of $\mathrm{O}_{2}^{-}$ production to pretreatment with PRL. This coincided well with the increased expression of the PRL-R gene in phagocytic leucocytes in SW. In the present study, hypophysectomy did not affect the level of PRL-R in the tilapia leucocytes (data not shown). According to Auperin et al. (1995), hypophysectomy had no influence on the kinetics of tilapia PRL-R in the gill. These observations indicate that local expression of the PRL-R gene may be independent of pituitary control, and that low levels of plasma PRL in SW-acclimated fish may not be the main cause of the increased gene expression of PRL-R, not only in osmoregulatory tissue but also in lymphoid cells.

There was no significant effect of $\mathrm{PRL}$ in $\mathrm{O}_{2}^{-}$production in leucocytes from SW-acclimated fish, whereas a slight but significant stimulation was seen in those from FW fish. This fact suggests that the increased level of PRL-R mRNA in leucocytes was not accompanied by a functional enhancement. In the silver sea bream (Sparus sarba), phagocytic activity of leucocytes from the head kidney was stimulated significantly after intraperitoneal injection of PRL both in FW- and in SW-acclimated fish, whereas no influence of environmental salinity was observed (Narnaware et al. 1998). In rainbow trout, SW acclimation enhanced the $\mathrm{O}_{2}^{-}$production in phagocytic leucocytes isolated from peripheral blood, and intraperitoneal administration of $\mathrm{GH}$ produced a further increase (Yada et al. 2001). The inconsistency of these observations may imply species-specific differences in the effects of environmental salinity and also of PRL and GH on fish immune functions. In view of the inhibitory action of PRL for hypo-osmoregulation in SW, an enhanced response of immune function to PRL in SW-acclimated tilapia accompanied by an increased expression of PRL-R suggests that the immunomodulatory actions of PRL may be independent of its osmoregulatory actions, at least in this euryhaline species.

It is well established that GH and PRL genes are expressed in the mammalian immune system as paracrine factors (Ben-Jonathan et al. 1996, Clark 1997). In coho salmon (Oncorhynchus kisutch) and rainbow trout, GH gene expression was detected in the kidney and intestine (Mori \& Devlin 1999, Yang et al. 1999). Expression of GH and PRL mRNA was detected in several lymphoid tissues, such as head kidney, spleen, thymus and intestine, as well as in leucocytes from blood and head kidney of the rainbow trout (Yada \& Azuma 2002). In the present study, ubiquitous expression of the two PRL genes was clearly shown in lymphoid tissues and also in leucocytes. Contamination with genomic DNA would appear to be unlikely since RNA samples were treated with DNase, 
and also since the primers for PCR were designed to distinguish the transcribed mRNA from genomic DNA. Although there may be a species-specific difference in the localization of GH and PRL mRNAs, results in this study suggest the importance of $\mathrm{GH}$ and PRL as paracrine factors in the tilapia immune system. The results of this study showed local expression of IGF-I in lymphoid tissues of the tilapia but not in the leucocytes isolated from the blood and head kidney. In mammals, some of the actions of $\mathrm{GH}$ in the immune system are mediated by local expression of IGF-I in the stromal cells of hemopoietic tissues (Clark 1997). The difference in the expression of IGF-I between lymphoid tissues and isolated leucocytes in tilapia may be related to the specific role of IGF-I during hemopoiesis. Further studies are called for on the mode of action of GH, PRL and their related factors, such as IGF-I, in modulating fish immune functions.

\section{Acknowledgements}

We are grateful to Professor M H Stetson, Department of Biological Sciences, University of Delaware, Dr N H Richman III, Mr S K Shimoda and Ms C Ball, Hawaii Institute of Marine Biology, University of Hawaii, for their support and encouragement during the course of this study. We are also indebted to Professors H Kawauchi, A Takahashi and S Moriyama, School of Fisheries Sciences, Kitasato University, for the supply of tilapia PRLs and GH. Thanks are also due to Professors T Mori, M Matsuda and Dr K Shiraishi, Department of Biological Science, Graduate School of Science, University of Tokyo, for the gift of plasmid containing tilapia PRL-R sequence, and to Dr N R Staten, Animal Agricultural Group, Monsanto, St Louis, $\mathrm{MO}$ for that of the $\mathrm{PRL}_{177}$ sequence. This study was supported by grants from the University of Hawaii Sea Grant College Program (No. NA86RG0041) and from the United States Department of Agriculture (No. 983506644). It was also funded by the International Cooperation conducted by the Science and Technology Agency, Japan. It was carried out according to the protocol of the animal care and use committee, University of Hawaii.

\section{References}

Auperin B, Rentier-Delrue F, Martial JA \& Prunet P 1994 Characterization of a single prolactin (PRL) receptor in tilapia (Oreochromis niloticus) which binds both $\mathrm{PRL}_{\mathrm{I}}$ and $\mathrm{PRL}_{\mathrm{II}}$. Journal of Molecular Endocrinology 13 241-251.

Auperin B, Rentier-Delrue F, Martial JA, \& Prunet P 1995 Regulation of gill prolactin receptors in tilapia (Oreochromis niloticus) after a change in salinity or hypophysectomy. Journal of Endocrinology 145 213-220.

Balm PHM 1997 Immune-endocrine interactions. In Fish Stress and Health in Aquaculture, pp 195-221. Eds GK Iwama, AD Pickerling, JP Sumpter \& CB Schreck. Cambridge: Cambridge University Press.
Ben-Jonathan N, Mershon JL, Allen DL \& Steinmetz RW 1996 Extrapituitary prolactin: distribution, regulation, functions, and clinical aspects. Endocrine Reviews 17 639-669.

Chen J-Y, Tsai H-L, Chang C-Y, Wang J-I, Shen S-C \& Wu J-L 1998 Isolation and characterization of tilapia (Oreochromis mossambicus) insulin-like growth factors gene and proximal promoter region. DNA and Cell Biology 17 359-376.

Clark R 1997 The somatogenic hormones and insulin-like growth factor-1: stimulants of lymphopoiesis and immune function. Endocrine Reviews 18 157-179.

Eckert SM, Yada T, Shepherd BS, Stetson MH, Hirano T \& Grau EG 2001 Hormonal control of osmoregulation in the channel catfish Ictalurus punctatus. General and Comparative Endocrinology 122 270-286.

Espelid S, Løkken GB, Steiro K \& Bøgwald J 1996 Effects of cortisol and stress on the immune system in Atlantic salmon Salmo salar L. Fish and Shellish Immunology 6 95-110.

Harris J \& Bird DJ 2000 Modulation of the fish immune system by hormones. Veterinary Immunology and Immunopathology 77 163-176.

McCormick SD 1995 Hormonal control of gill $\mathrm{Na}^{+}, \mathrm{K}^{+}$-ATPase and chloride cell function. In Cellular and Molecular Approaches to Fish Ionic Regulation, pp 285-315. Eds CM Wood \& TJ Shuttleworth. San Diego: Academic Press.

Marc AM, Quentel C, Severe A, Le Bail PY \& Boeuf G 1995 Changes in some endocrinological and non-specific immunological parameters during seawater exposure in the brown trout. Journal of Fish Biology 46 1065-1081.

Mori T \& Devlin RH 1999 Transgene and host growth hormone gene expression in pituitary and nonpituitary tissues of normal and growth hormone transgenic salmon. Molecular and Cellular Endocrinology 149 129-139.

Narnaware YK, Kelly SP \& Woo NYS 1998 Stimulation of macrophage phagocytosis and lymphocyte count by exogenous prolactin administration in silver sea bream (Sparus sarba) adapted to hyper- and hypo-osmotic salinities. Veterinary Immunology and Immunopathology 61 387-391.

Nishioka RS 1980 Hypophysectomy of tilapia (Sarotherodon mossambicus) through the orbit. General and Comparative Endocrinology 40 377-378.

Prunet P, Sandra O, Le Rouzic P, Marchand O \& Laudet V 2000 Molecular characterization of the prolactin receptor in two fish species, tilapia Oreochromis niloticus and rainbow trout, Oncorhynchus mykiss: a comparative approach. Canadian Journal of Physiology and Pharmacology 78 1086-1096.

Reinecke M, Schmid A, Ermatinger R \& Loffing-Cueni D 1997 Insulin-like growth factor I in the teleost Oreochromis mossambicus, the tilapia: gene sequence, tissue expression, and cellular localization. Endocrinology 138 3613-3619.

Sakai M, Kobayashi M \& Kawauchi H 1996a Mitogenic effect of growth hormone and prolactin on chum salmon Oncorhynchus keta leukocytes in vitro. Veterinary Immunology and Immunopathology $\mathbf{5 3}$ 185-189.

Sakai M, Kobayashi M \& Kawauchi H 1996 In vitro activation of fish phagocytic cells by GH, prolactin and somatolactin. Journal of Endocrinology 151 113-118.

Sakamoto T, Ogasawara T \& Hirano T 1990 Growth hormone kinetics during adaptation to a hyperosmotic environment in rainbow trout. Journal of Comparative Physiology B 160 1-6.

Sakamoto T, Shepherd BS, Madsen SS, Nishioka RS, Siharath K, Richman NH III, Bern HA \& Grau EG 1997 Osmoregulatory actions of growth hormone and prolactin in an advanced teleost. General and Comparative Endocrinology 106 95-101.

Sandra O, Sohm F, de Luze A, Prunet P, Edery M \& Kelly PA 1995 Expression cloning of a cDNA encoding a fish prolactin receptor. PNAS 92 6037-6041. 
Sandra O, Le Rouzic P, Cauty C, Edery M \& Prunet P 2000 Expression of the prolactin receptor (tiPRL-R) gene in tilapia Oreochromis niloticus: tissue distribution and cellular localization in osmoregulatory organs. Journal of Molecular Endocrinology 24 215-224.

Sandra O, Le Rouzic P, Rentier-Delrue F \& Prunet P 2001 Transfer of tilapia (Oreochromis niloticus) to a hyperosmotic environment is associated with sustained expression of prolactin receptor in intestine, gill, and kidney. General and Comparative Endocrinology 123 295-307.

Sekkali B, Brim H, Muller M, Argenton F, Bortolussi M, Colombo L, Belayew A \& Martial JA 1999 Structure and functional analysis of a tilapia (Oreochromis mossambicus) growth hormone gene: activation and repression by pituitary transcription factor Pit-1. DNA and Cell Biology 18 489-502.

Shepherd BS, Ron B, Burch A, Sparks A, Richman NH III, Shimoda SK, Stetson MH, Lim C \& Grau EG 1997a Effects of salinity, dietary level of protein and $17 \alpha$-methyltestosterone on growth hormone $(\mathrm{GH})$ and prolactin $\left(\mathrm{tPRL}_{177}\right.$ and $\mathrm{tPRL}_{188}$ ) levels in the tilapia, Oreochromis mossambicus. Fish Physiology and Biochemistry 17 279-288.

Shepherd BS, Sakamoto T, Nishioka RS, Richman NH III, Mori I, Madsen SS, Chen TT, Hirano T, Bern HA \& Grau EG $1997 b$ Somatotropic actions of the homologous growth hormone and prolactins in the euryhaline teleost, the tilapia, Oreochromis mossambicus. PNAS 94 2068-2072.

Shiraishi K, Matsuda M, Mori T \& Hirano T 1999 Changes in expression of prolactin- and cortisol-receptor genes during early-life stages of euryhaline tilapia (Oreochromis mossambicus) in fresh water and seawater. Zoological Science 16 139-146.

Specker JL, King DS, Nishioka RS, Shirahata K, Yamaguchi K \& Bern HA 1985 Isolation and partial characterization of a pair of prolactins released in vitro by the pituitary of the cichlid fish, Oreochromis mossambicus. PNAS 82 7490-7494.

Swennen D, Poncelet A-C, Sekkali B, Rentier-Delrue F, Martial JA \& Belayew A 1992 Structure of the tilapia (Oreochromis mossambicus) prolactin I gene. DNA and Cell Biology 11 673-684.
Takemura A 1993 Changes in an immunoglobulin M (IgM)-like protein during larval stages in tilapia, Oreochromis mossambicus. Aquaculture 115 233-241.

Takemura A \& Takano K 1995 Lysozyme in the ovary of tilapia (Oreochromis mossambicus): its purification and some biological properties. Fish Physiology and Biochemistry 14 415-421.

Takeuchi K 2000 GeneBank accession number AB037865.

Yada T \& Azuma T 2002 Hypophysectomy depresses immune functions of the rainbow trout. Comparative Biochemistry and Physiology C 131 93-100.

Yada T, Hirano T \& Grau EG 1994 Changes in plasma levels of the two prolactins and growth hormone during adaptation to different salinities in the euryhaline tilapia, Oreochromis mossambicus. General and Comparative Endocrinology 93 214-223.

Yada T, Nagae M, Moriyama S \& Azuma T 1999 Effects of prolactin and growth hormone on plasma immunoglobulin M levels of hypophysectomized rainbow trout, Oncorhynchus mykiss. General and Comparative Endocrinology 115 46-52.

Yada T, Azuma T \& Takagi Y 2001 Stimulation of non-specific immune functions in seawater-acclimated rainbow trout, Oncorhynchus mykiss, with reference to the role of growth hormone. Comparative Biochemistry and Physiology B 129 695-701.

Yamaguchi K, Specker JL, King DS, Yokoo Y, Nishioka RS, Hirano T \& Bern HA 1988 Complete amino acid sequences of a pair of fish (tilapia) prolactins, $\mathrm{tPRL}_{177}$ and $\mathrm{PPRL}_{188}$. Journal of Biological Chemistry 263 9113-9121.

Yamaguchi K, King DS, Specker JL, Nishioka RS, Hirano T \& Bern HA 1991 Amino acid sequence of growth hormone isolated from medium of incubated pituitary glands of tilapia (Oreochromis mossambicus). General and Comparative Endocrinology 81 323-331.

Yang B-Y, Greene M \& Chen TT 1999 Early embryonic expression of the growth hormone family protein genes in the developing rainbow trout, Oncorhynchus mykiss. Molecular Reproduction and Development $\mathbf{5 3} 127-134$.

Received 5 November 2001

Accepted 8 February 2002 